\title{
Primary small cell type of non-Hodgkin lymphoma of the colon: a case report
}

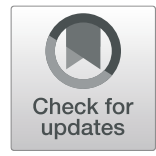

Eyal Meir ${ }^{1,2}$, Chovav Handler ${ }^{1,2}$, Uri Kaplan ${ }^{1,2}$, Doron Kopelman ${ }^{1,2}$ and Ossama A. Hatoum ${ }^{1,2^{*}}$

\begin{abstract}
Introduction: Primary lymphoma of the colon is exceedingly rare and comprises $0.2-1 \%$ of all colon tumors. The most common subtype of lymphoma in the colon is non-Hodgkin lymphoma. Symptoms are often nonspecific, and treatment varies between chemotherapy alone and a combination of surgery and chemotherapy.

Case presentation: We describe a case of a Ashkenazi Jew patient who presented in the typical way that carcinoma of the colon might present but turned out to have a very rare type of tumor in both its histology and its location.

Conclusion: There was apparent discordance between the relative bulkiness and gross appearance of the tumor with the unrevealing result of the biopsies, demanding a high level of suspicion as to the actual presence and possible type of such a tumor in the future.
\end{abstract}

Keywords: Case report, Colon, Lymphoma

\section{Introduction}

Primary lymphoma of the colon is exceedingly rare and comprises $0.2-1 \%$ of all colon tumors [1-4]. The most common subtype of lymphoma in the colon is nonHodgkin lymphoma (NHL) [5]. Though the most common site for secondary spread of lymphoma is the gastrointestinal (GI) tract, primary lymphoma of the GI tract accounts for only $10-15 \%$ of all lymphomas. The most common GI location for primary lymphoma is the stomach $25-50 \%$, followed by the small intestine $(20-$ $30 \%)$. The colon and rectum account for the remaining $10-20 \%[6,7]$. Symptoms are often nonspecific, and treatment varies between chemotherapy alone and a combination of surgery and chemotherapy [8].

\section{Case presentation}

A 57-year-old Ashkenazi Jew woman, who aside from iron deficiency anemia was relatively well, with no family or personal history of malignancy, was admitted to our

\footnotetext{
* Correspondence: Ohatoum@gmail.com

${ }^{1}$ Department of Surgery B, Emek Medical Center, Afula, Israel

${ }^{2}$ Rapaport Faculty of Medicine, Technion-Israel Institute of Technology, Haifa, Israel
}

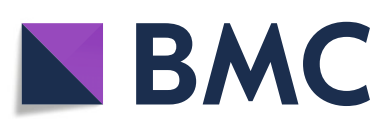

(c) The Author(s). 2020 Open Access This article is licensed under a Creative Commons Attribution 4.0 International License, which permits use, sharing, adaptation, distribution and reproduction in any medium or format, as long as you give appropriate credit to the original author(s) and the source, provide a link to the Creative Commons licence, and indicate if changes were made. The images or other third party material in this article are included in the article's Creative Commons licence, unless indicated otherwise in a credit line to the material. If material is not included in the article's Creative Commons licence and your intended use is not permitted by statutory regulation or exceeds the permitted use, you will need to obtain permission directly from the copyright holder. To view a copy of this licence, visit http://creativecommons.org/licenses/by/4.0/ The Creative Commons Public Domain Dedication waiver (http://creativecommons.org/publicdomain/zero/1.0/) applies to the data made available in this article, unless otherwise stated in a credit line to the data. verse colon tumor. Four months prior, she had begun periencing periumbilical abdominal pain hematochezia, and she had a 10-kg weight loss. Upon physical examination, no masses were palpated, and there were no other pathologic findings. She underwent a colonoscopy, which revealed a large mass that involved nearly the whole circumference of the colon and seemed to be adjacent to the cecum. Biopsies were taken that failed to demonstrate any colonic pathology. She proceeded to undergo computed tomography (CT) of the chest and abdomen that demonstrated a huge mass that occupied the whole colonic lumen and caused a colocolic intussusception (Fig. 1). Considerable mesenteric lymphadenopathy was seen with nodes up to $28 \times 21 \mathrm{~mm}$ in diameter and was deemed to be evidence of positive tumoral lymph node involvement (Fig. 2). No inguinal, pelvic, retroperitoneal, or other lymphadenopathy was seen. Considering the gross endoscopic and CT findings, she was scheduled for surgery. A laparoscopic right extended hemicolectomy was performed, which was uncomplicated, and during which considerable mesocolic lymphadenopathy was seen and widely resected accordingly. 


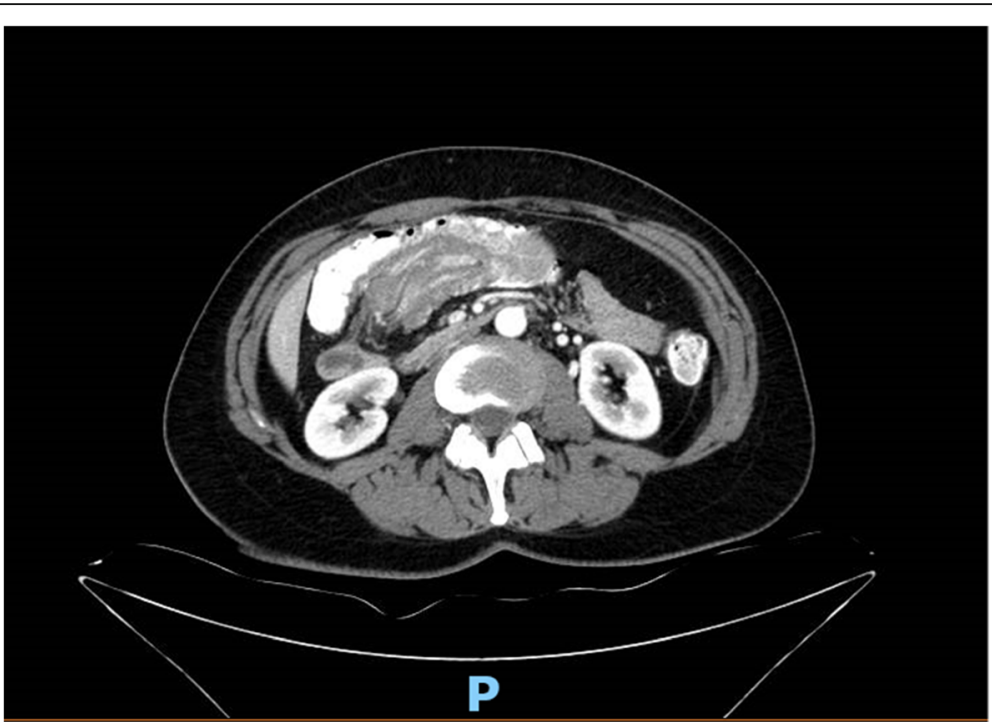

Fig. 1 Initial presentation with a huge mass that occupies the whole colonic lumen and causes a colocolic intussusception (arrow)

Pathology of the surgical specimen showed findings consistent with small B cell lymphoproliferative disorders (LPDs) with plasmacytoid differentiation. At this point, though primary lymphoma of the colon was considered in the differential diagnosis, the disease was thought to be part of systemic dissemination of lymphoma. The patient was referred to the hematology clinic for further investigation. A bone marrow biopsy was performed, and the result was normal. The investigation was complemented by positron emission tomographyCT, which showed no other focus of lymphoma. Also, the result of a test for Epstein-Barr virus infection as a possible predisposing factor for lymphoma was negative. These results support the diagnosis of a primary colonic NHL small B-cell LPD with plasmacytoid differentiation, an exceedingly rare disease with only two such reports in the current literature $[2,9]$.

\section{Discussion}

B-cell lymphoma is the third most common tumor of the colon (following adenocarcinoma and carcinoid) but still comprises only $0.5 \%$ of all colonic tumors [10]. Despite its rarity, it should be noted that its frequency seems to be rising, especially in North America [11]. It is thought that primary NHL of the colon arises from mucosa-associated lymphatic tissue of the colon [5]. The subtype diffuse large B-cell lymphoma is the most common subtype, and the most common colonic site for this tumor is the cecum [5]. This is presumably due to the excess of lymphatic tissue in this region. The cecum is

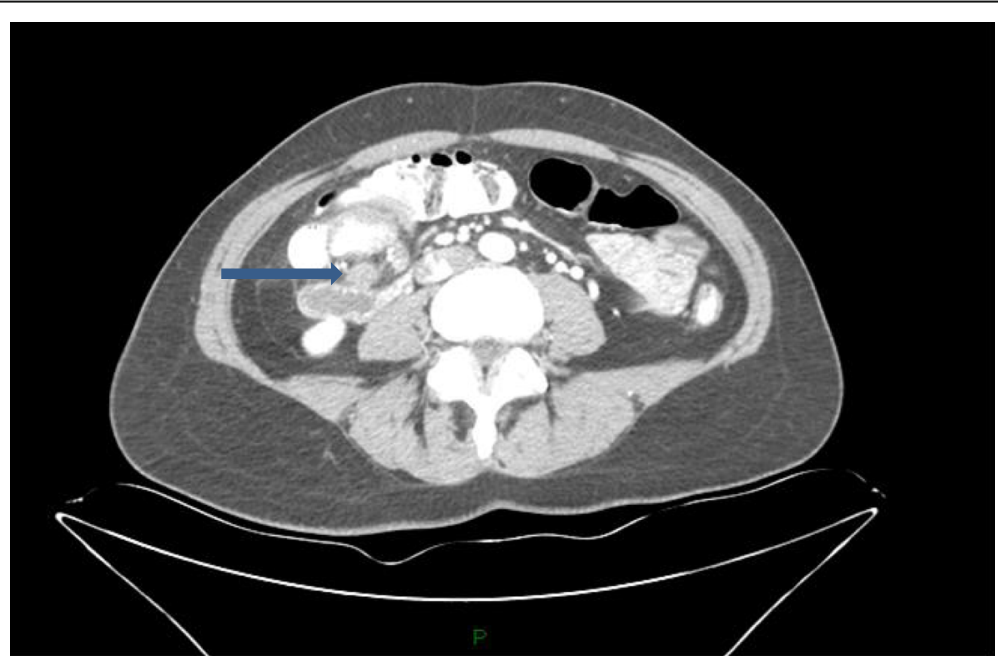

Fig. 2 Considerable mesenteric lymphadenopathy (arrow) 
then followed by the right colon and the sigmoid colon. Symptoms described in the literature are varied and include abdominal pain, weight loss, hematochezia, abdominal mass, intussusception, intestinal obstruction, and even perforation and peritonitis $[1,3,5,10]$, and it is estimated that $20 \%$ of patients require emergent surgery [11]. This disease usually affects older people (the median age is older than 55 years) and mostly men [12]. Risk factors for colonic NHL are autoimmune diseases such as inflammatory bowel disease, celiac disease, and human immunodeficiency virus carrier status [13]. The treatment of colonic lymphoma includes a combination of surgery and chemotherapy [14] and depends on the staging of the disease. The lower stages of disease are treated with surgery and complemented by adjuvant polychemotherapy, whereas the more advanced stages are treated with multidrug chemotherapy (mostly CHOP [cyclophosphamide, doxorubicin, vincristine, prednisone]), or other combinations of chemotherapy and rituximab (R-CHOP [cyclophosphamide, doxorubicin, vincristine, prednisone, rituximab]) $[10,11,15]$. A recent review of the literature [10] that covered 20 publications regarding colonic lymphoma included only 2 cases of small cell lymphoma.

\section{Conclusions}

In this case report, we describe a patient who presented in the typical way that carcinoma of the colon might present but turned out to have a very rare type of tumor in both its histology and its location. There was an apparent discordance between the relative bulkiness and gross appearance of the tumor and the unrevealing result of the biopsies. This type of case, in which the pathology is not conducive, demands that we maintain a high level of suspicion as to the actual presence and possible type of such a tumor. It demands that we remain familiar with the presentation and treatment options of the colonic lymphomas.

\section{Acknowledgements}

Not applicable.

\section{Authors' contributions}

$\mathrm{EM}$ and $\mathrm{CH}$ participated in the sequence alignment and drafting of the manuscript. UK participated in the design of the figures. DK participated in the sequence alignment. OAH conceived of the study and participated in its design and coordination and helped to draft the manuscript. The authors read and approved the final manuscript.

\section{Funding}

No funding.

\section{Availability of data and materials}

Data sharing is not applicable to this article, because no datasets were generated or analyzed during the present study.

Ethics approval and consent to participate Not applicable.

\section{Consent for publication}

Written informed consent was obtained from the patient for publication of this case report and any accompanying images. A copy of the written consent is available for review by the Editor-in-Chief of this journal.

\section{Competing interests}

The authors declare that they have no competing interests.

Received: 30 May 2020 Accepted: 17 August 2020

Published online: 19 September 2020

\section{References}

1. Zinzani PL, Magagnoli M, Pagliani G, Bendandi M, Gherlinzoni F, Merla E, et al. Primary intestinal lymphoma: clinical and therapeutic features of 32 patients. Haematologica. 1997;82:305-8.

2. Doolabh N, Anthony T, Simmang C, Bieligk S, Lee E, Huber P, et al. Primary colonic lymphoma. J Surg Oncol. 2000;74:257-62.

3. Bairey O, Ruchlemer R, Shpilberg O. Non-Hodgkin's lymphomas of the colon. Isr Med Assoc J. 2006:8:832-5.

4. Wong MT, Eu KW. Primary colorectal lymphomas. Colorectal Dis. 2006;8(7): 586-91.

5. Gonzalez QH, Heslin MJ, Davila-Cervantes A, Alvarez-Tostado J, de los Monteros AE, Shore G, et al. Primary colonic lymphoma. Am Surg. 2008;74: 214-6.

6. Barbaryan A, Ali AM, Kwatra SG, et al. Primary diffuse large B-cell lymphoma of the ascending colon. Rare Tumors. 2013:5(2):85-8.

7. Koch P, del Valle F, Berdel WE, et al. Primary gastrointestinal non-Hodgkin's lymphoma: I. Anatomic and histologic distribution, clinical features, and survival data of 371 patients registered in the German Multicenter Study GIT NHL 01/92. J Clin Oncol. 2001;19:3861-73.

8. Stanojevic GZ, Nestorovic MD, Brankovie BR, et al. Primary colorectal lymphoma: an overview. World J Gastrointest Oncol. 2011;3:14-8.

9. Pandey M, Wadhwa MK, Patel DD, Kothari KC. Primary malignant large bowel lymphoma. Am Surg. 2002;68:121-6.

10. Pandey M, Swain J, lyer HM, Shukla M. Primary lymphoma of the colon: report of two cases and review of literature. World J Surg Oncol. 2019;17:18.

11. Lightner AL, Shannon E, Gibbons MM, Russell MM. Primary gastrointestinal non-Hodgkin's lymphoma of the small and large intestines: a systematic review. J Gastrointest Surg. 2016;20(4):827-39.

12. Chang SC. Clinical features and management of primary colonic lymphoma. Formosan J Surg. 2012;45:73-7.

13. Peng JX, Wang LZ, Tan ZJ, et al. Concomitant non-Hodgkin's lymphoma in colon and liver: report of a rare case and review of literature. Int J Clin Exp Pathol. 2015:8:3257-61.

14. Tondini C, Giardini R, Bozzetti F, Valagussa P, Santoro A, Bertulli R, et al. Combined modality treatment for primary gastrointestinal non-Hodgkin's Iymphoma: the Milan cancer Institute experience. Ann Oncol. 1993;4:831-7.

15. Won RP, Lin MY, Williams JL, Petrie BA. Primary colonic lymphoma. J Gastrointest Surg. 2018;22(2):361-2.

\section{Publisher's Note}

Springer Nature remains neutral with regard to jurisdictional claims in published maps and institutional affiliations.
Ready to submit your research? Choose BMC and benefit from:
- fast, convenient online submission
- thorough peer review by experienced researchers in your field
- rapid publication on acceptance
- support for research data, including large and complex data types
- gold Open Access which fosters wider collaboration and increased citations
- maximum visibility for your research: over $100 \mathrm{M}$ website views per year
At BMC, research is always in progress.
Learn more biomedcentral.com/submissions 